\title{
Effect of pretreatments and processing conditions on anti-nutritional factors in climbing bean flours
}

\author{
Emmanuel Mugabo ${ }^{a}$, Emmanuel Ohene Afohkwa $^{\mathrm{a}}$, George Annor $^{\mathrm{a}}$, And Bernard \\ RWUBATSE $^{\mathrm{B}^{*}}$ \\ ${ }^{\mathrm{a}}$ University of Ghana, Legon, Ghana \\ ${ }^{\mathrm{b}}$ University of Rwanda-College of Agriculture, Animal Sciences and Veterinary Medicine, School of Food \\ Science and Technology, Rwanda \\ ${ }^{*}$ Corresponding author \\ habyalijean@yahoo.fr \\ TEL: +250788691468
}

Received: 08 August 2016; Published online: 18 April 2017

\begin{abstract}
It is difficult for many Rwandans to utilize climbing bean seeds (Phaseolus vulgaris $\mathrm{L}$.) mainly because of longer cooking time ( 2 hours) and the high consumption of basic fuel. Climbing beans also contain anti-nutritional factors such tannins, phytates, trypsin inhibitors and phytohemagglutinins that limit nutrient absorption. One way to solve this problem is to utilize the flour of climbing beans made from different treatments and processing methods. In this study, climbing beans were pre-treated by soaking them in water for 24 hours, soaking in $2 \%$ sodium bicarbonate solution and steam blanching for 10 minutes. After that, pre-treated climbing beans were processed into flours by processing methods such as roasting, cooking and germination where anti-nutritional factors were reduced. The pretreatments did not significantly $(\mathrm{p}>0.05)$ affect phytates in climbing bean flours but processing conditions significantly $(\mathrm{p}<0.05)$ reduced it. Pretreatments and processing conditions significantly $(\mathrm{p}<0.05)$ reduced tannin content. The pretreatments followed by different processing conditions significantly $(\mathrm{p}<0.05)$ decreased trypsin inhibitors content. The great significant decrease in phytohemagglutinins content was observed in pretreatment followed by different processing methods. All pretreatments and processing conditions effectively decreased anti-nutritional factors at low level. However, pretreatments or untreated followed by germination and roasting were found to be the most and the least effective respectively. Making flour from germinated climbing bean seeds is a good option for sustainable food processing as it reduces anti-nutritional factors. It is an inexpensive method in terms of time, energy and fuel for Rwandan households, restaurants and industries where climbing bean seeds are integral part of daily meal.
\end{abstract}

Keywords: Climbing beans; Pre-treatments; Processing; Anti-nutritional factors

\section{Introduction}

Climbing beans (Phaseolus vulgaris L.) are mostly grown in Rwanda and they are consumed by a large part of the population (Larochelle \& Alwang, 2014) particularly those living in rural areas. The climbing beans are among the varieties of beans developed by the Rwanda
Agriculture Board (RAB) in collaboration with the International Centre for Tropical Agriculture (Jones \& Boulter, 1983). Climbing beans are consumed as green leaves, pods and fresh or dry grains (Broughton et al., 2003). They are often considered by Rwandese people as the meat of the poor because of their high protein content 
Effect of processing conditions on anti-nutritional factors in climbing bean flours $\mid 35$

and affordability (Larochelle \& Alwang, 2014). Beans provide $32 \%$ of calories and $65 \%$ of protein intake in the Rwandan diet whereas proteins sourced from animals provide only $4 \%$ of the protein intake (Asare-Marfo et al., 2011). Dry bean consumption is however limited by long cooking time. For example, climbing beans are prone to hard-to-cook defects, which lead to high fuel requirement and reduced acceptability, digestibility and consumption. Climbing beans also contain toxic substances such as saponins, trypsin inhibitors, cyanogenetic, phytates, tannins, glycosides proteases and amylases inhibitors and hemagglutinins (Durward, Jerry, Wai-kit, \& Nip, 1997). In an attempt to reduce many of these problems, this investigation dealt with the various pre-treatments and processing conditions used to make flour from dry climbing bean seeds where anti-nutrients, cooking energy, time, consumption and amount of water needed are reduced. The objective of this research was to assess the effects of different pre-treatment and processing conditions on the anti-nutrients of the climbing bean flours.

Hence, it will provide the preliminary information and further the knowledge about how to cook climbing bean in a short time using new technology and the effective utilization of climbing bean flour in various food applications in Rwanda and other parts of the worlds.

\section{Materials and Methods}

\subsection{Materials}

Climbing bean seed samples used for this study were provided by Rwanda Agriculture Board. The beans were thoroughly cleaned and sorted to remove extraneous matter, like stones and dry leaves. After that, the beans were divided into two parts and stored at room temperature (20 ${ }^{\circ} \mathrm{C}$ ) and used for the different experiments for seeds and flours respectively.

\section{Preparation of climbing bean seed samples}

\section{Preparation of untreated climbing bean seed samples}

The raw pre-cleaned climbing bean seeds were package in polyethylene bag and stored at room temperature $\left(20^{\circ} \mathrm{C}\right)$ before processing.

\section{Preparation of climbing bean seed samples soaked in water}

The dry cleaned climbing bean seeds that were free from dirt and others foreign materials like stone and leaves were soaked in distilled water for 24 hours at room temperature $\left(20{ }^{\circ} \mathrm{C}\right)$. The soaked seeds were drained using absorbent paper and rinsed twice. After that, the soaked beans were spread on the trays and dried in oven at $50{ }^{\circ} \mathrm{C}$ for 24 hours. The dried seeds were cooled at room temperature and packed in polyethylene bags and stored at room temperature $\left(20^{\circ} \mathrm{C}\right)$ before processing.

\section{Preparation of climbing bean seed samples soaked in $2 \%$ sodium bicarbonate solution}

The dry cleaned climbing bean seeds were soaked in distilled water containing $2 \%(\mathrm{w} / \mathrm{v})$ of sodium bicarbonate salt solution (prepared using standard grade laboratory chemicals) for 24 hours at room temperature $\left(20{ }^{\circ} \mathrm{C}\right)$. After that, soaked beans were drained using absorbent paper and dried in oven at $50{ }^{\circ} \mathrm{C}$ for 24 hours. The dried beans were stored in polyethylene bags at room temperature $\left(20^{\circ} \mathrm{C}\right)$ for further processing.

\section{Preparation of blanched climbing bean seed samples}

The dry cleaned climbing beans seeds were put in perforated blanching baskets in steam over boiling water at $100{ }^{\circ} \mathrm{C}$ in an aluminium pot and covered. After $10 \mathrm{~min}$, seeds were removed and drained using absorbent paper. The blanched beans were dried in an oven at $50{ }^{\circ} \mathrm{C}$ for 24 hours. The dried beans were packed in polyethylene bag and stored at room temperature $\left(20^{\circ} \mathrm{C}\right)$ prior to use for further processing. 


\section{Preparation of climbing bean flours}

\section{Preparation of germinated samples}

The pre-treated and un-treated climbing bean seeds were soaked separately in deionised water for 9 hours at room temperature $\left(20{ }^{\circ} \mathrm{C} \pm 1{ }^{\circ} \mathrm{C}\right)$. After that, seeds were drained using a perforated aluminium pan. The soaked seeds were kept separately between thick layers of cotton cloth and allowed to germinate in dark place for 4 days. Seeds were washed manually with distilled water then dried in oven at $50{ }^{\circ} \mathrm{C}$ for 24 hours. Seeds were then cooled in desiccator for $30 \mathrm{~min}$. The dried seeds were milled into flour using a Philips laboratory blender (Model HR2811, Chichester, UK) and sieved using a $60 \mathrm{~mm}$ mesh (British standard). The flour obtained was packed in high density polyethylene bags and stored in a refrigerator at $10{ }^{\circ} \mathrm{C}$ prior to use.

\section{Preparation of roasted samples}

The pre-treated and untreated climbing bean seeds were roasted in laboratory on a hot aluminium pan separately using a $1000 \mathrm{~W}$ electric hot plate (Guangzhou D.G.H. Electrical Appliances Co. Ltd., Guangdong, China) as the source of heat. Before roasting, the pan was warmed to a temperature $60{ }^{\circ} \mathrm{C}-70{ }^{\circ} \mathrm{C}$. After that, the samples were added and heated until the temperature reached $120{ }^{\circ} \mathrm{C}$. During roasting, the climbing beans seeds were continuously stirred until the browning that indicates complete roasting colour appeared. After that, the seeds were cooled in a desiccator for $30 \mathrm{~min}$. The roasted seeds were then ground into flour by using a Philips laboratory blender (Model HR2811, Chichester, UK) and sieved using $60 \mathrm{~mm}$ mesh (British standard). The flours were packed in high density polyethylene bags and stored in a refrigerator at $10{ }^{\circ} \mathrm{C}$ prior to use.

\section{Preparation of cooked samples}

Pre-treated and untreated dry climbing beans seed were separately taken for cooking. The cooking was done in the laboratory for 2 hours at $98^{\circ} \mathrm{C}$ using an open aluminium pot on an electric hot plate (Guangzhou D.G.H. Electrical Appliances Co. Ltd. Guangdong, China) as the source of heat. At the end of the cooking time, water was drained and the seeds were dried separately in oven at $50{ }^{\circ} \mathrm{C}$ for 24 hours. After that, the seeds were cooled in desiccator for $30 \mathrm{~min}$. The dried cooked pre-treated and untreated climbing beans were finally milled using a Philips laboratory blinder (Model HR2811, Chichester, UK) and sieved using $60 \mathrm{~mm}$ mesh (British standard) to obtain cooked climbing bean flours. The flours produced were packed in high density polyethylene bags and stored in a refrigerator at $10{ }^{\circ} \mathrm{C}$ prior to use.

\subsection{Experimental design}

The study adopted a $4 \times 4$ factorial experimental design. Pre-treatments (soaking in water for 24 hours, soaking in $2 \%$ sodium bicarbonate for 24 hours, steam blanching for $10 \mathrm{~min}$ and no pre-treatment) together with processing conditions (raw, cooked, germinated and roasted) were used.

\section{Determination of anti-nutritional factors}

\section{Determination of phytohemagglutinins}

Phytohemagglutinins were determined as described by Oshodi and Aletor (1993) but with slight modifications. Two (2) gram of sample were weighed into $250 \mathrm{~mL}$ beaker, and 50 $\mathrm{mL}$ of solvent mixture of isobutyl alcohol and trichloroacetic acid were added and allowed to be continuously shaking for 6 hours to extract the hemagglutinins. The mixture was filtered through a double layer filter paper into a 250 $\mathrm{mL}$ conical flask and maintained in a water bath for 2 hours at $80{ }^{\circ} \mathrm{C}$ and the filtrate was allowed to cool. A set of standard solutions of hemagglutinin ranging from 0 to $10 \mathrm{ppm}$ were prepared from hemagglutinins stock solution. The absorbance of the standard solution as well as that of the filtrate were read at $220 \mathrm{~nm}$ on a digital spectrophotometer 21D.

$$
\% \text { phytohemagglutinins }=\frac{A p \times A g \times D f}{10,000}
$$


Effect of processing conditions on anti-nutritional factors in climbing bean flours $\mid 37$

Ap Absorbance of sample

Ag Average gradient of standard

Df Dilution factor

\section{Determination of tannins content}

Tannins content was determined by the method described by Pearson (1976). One gram of sample was dispersed in $10 \mathrm{~mL}$ distilled water and agitated. This was left to stand for $30 \mathrm{~min}$ at room temperature $\left(20 \pm 2{ }^{\circ} \mathrm{C}\right)$, after which it was centrifuged to get the extract. About $2.5 \mathrm{~mL}$ of the supernatant (extract) was pipetted into a $50 \mathrm{~mL}$ volumetric flask. Similarly, $2.5 \mathrm{~mL}$ of standard tannic acid solution was pipetted into a separate $50 \mathrm{~mL}$ flask. One millilitre of Folin-Denis reagent was measured into each flask, followed by $2.5 \mathrm{~mL}$ of saturated $\mathrm{Na}_{2} \mathrm{CO}_{3}$ solution. The mixture was made up to mark in a $50 \mathrm{~mL}$ flask and incubated for $90 \mathrm{~min}$ at room temperature. The absorbance was measured at $250 \mathrm{~nm}$ with a spectrophotometer (Genway model 6000). Readings were taken with the reagent blank at zero. Tannin content was calculated as follows:

$$
\% \text { Tannins }=\frac{A n}{A s} \times C \times \frac{100}{W} \times \frac{V f}{V a}
$$

Where

An Absorbance of test material

As Absorbance of standard solution

C Concentration of standard solution

W Weight of sample

Vf Total volume of extract

Va Volume of extract analyzed

\section{Determination of phytates}

The method described by Nwosu (2011) was used. The phytic acid in the samples was precipitated with excess $\mathrm{FeCl}_{3}$ after extraction of 1 $\mathrm{g}$ of each sample with $100 \mathrm{~mL} 0.5 \mathrm{~N} \mathrm{HCl}$. The precipitate was converted to sodium phytate using $2 \mathrm{~mL}$ of $2 \% \mathrm{NaOH}$ before digestion with an acid mixture $(1 \mathrm{~mL})$ containing equal portions of conc. $\mathrm{H}_{2} \mathrm{SO}_{4}$ and $65 \% \mathrm{HClO}_{4}$. The liberated phosphorus was measured colorimetrically (Jenway 6051 Colorimeter) at $520 \mathrm{~nm}$ after colour development (brownish-yellow) with molybdate solution. The percentage phytates was thus calculated:

$$
\% \text { Phytates }=\frac{100}{W} \times \frac{a u}{a s} \times C \times \frac{V t}{V a}
$$

Where

W weight of sample used

au absorbance of test sample

as absorbance of standard phytate solution

C Concentration of standard phytate solution

Vt Total volume of extract

Va Volume of extract analyzed

\section{Determination of trypsin inhibitors}

This was done using the spectrophotometric method, described by Nwosu (2011). A measured weight $(10 \mathrm{~g})$ of the test sample was dispersed in $50 \mathrm{~mL}$ of $0.5 \mathrm{M} \mathrm{NaCl}$ solution and stirred for $30 \mathrm{~min}$ at room temperature. It was centrifuged and the supernatant filtered through Whatman No.42 filter paper. The filtrate was then used for the assay. Standard trypsin was prepared and used to treat the substrate solution (N-benzoylDL-arginine-p-anilide; BAPA). The extent of inhibition was used as a standard for measuring the trypsin inhibitory activity of the test sample extract into a test tube containing $2 \mathrm{~mL}$ of extract and $10 \mathrm{~mL}$ of the substrate (BAPA), $2 \mathrm{~mL}$ of the standard trypsin solution was added. Also $2 \mathrm{~mL}$ of the standard trypsin solution was added in another test tube containing only $10 \mathrm{~mL}$ of the substrate. The latter served as the blank.

The content of the tubes was allowed to stand for 30 min and then absorbance of the solution measured at $430 \mathrm{~nm}$ wavelength with a colorimeter 
(Jenway 6051). One trypsin activity-unit inhibited is given by an increase of 0.01 absorbance unit at $430 \mathrm{~nm}$. Trypsin activity-unit inhibition was calculated thus:

$$
\text { Trypsin unit inhibited }=\frac{A u}{A s} \times 0.001 \times F
$$

Where

Au Absorbance of test sample

As Absorbance of standard (uninhibited) sample

F Experimental factor given as: $=\frac{V f}{V a \times W}$

Where

Vf Total volume of extract

Va Volume of extract analyzed

W Weight of sample analyzed.

Trypsin inhibitor was expressed as number of trypsin unit inhibited (TIU) per unit weight (gram) of the sample analysed

\section{Statistical analysis}

The data were analysed using Minitab version 14.0 software for analysis of variance (ANOVA). Least significant difference (LSD) was used to separate and compare the means, and significant difference was accepted at $\mathrm{p}<0.05$. All treatments and analyses were conducted in triplicates.

\section{Results and Discussion}

Phytic acid in climbing beans reduces protein digestibility and availability of minerals by chelating mineral cations such as $\mathrm{Zn}^{2+}, \mathrm{Fe}^{2}, \mathrm{Ca}^{2+}$ and interacts with proteins to form insoluble complexes (Oatway, Vasanthan, \& Helm, 2001). On the other hand, when phytate is used at low level $(0.1-0.9 \%)$ as reported by Yoon, Thompson, and Jenkins (1983), it contributes to anticarcinogenic and anti-oxidant properties and reduces blood cholesterol response (Shamsuddin,
2002; Minihane \& Rimbach, 2002). In addition, phytate also could be used in reducing triglycerides and prevention of renal stone development (Kumar, Sinha, Makkar, \& Becker, 2010). Phytic acid varied between $2.42 \%$ to $0.04 \%$ (Table 1 ). The phytate in untreated climbing bean flours was found to be $2.42 \%$. This value was lower than $7.8 \%$ in raw white beans, $9.11 \%$ in raw black beans, 5.43 in raw kidney beans (Sangronis \& Machado, 2007; Kar, Choudhary, \& Bandyopadhyay, 1999). During germination process, phytic acid provides phosphorus and mineral for the seed to germinate. At the same time, phosphate and inositol are generated due to hydrolysis of phytate by enzymes phytase. All processing methods reduced significantly phytate. The highest phytate reduction was observed in pretreated climbing bean flours followed by processing like cooking, roasting and germination, which was the best way to reduce phytic acid in climbing bean flours. This was probably due to an increase in phytase activity as reported in broad beans, chickpea by Egli, Davidsson, Juillerat, Barclay, and Hurrell (2002). Soaking and steam blanching also decreased phytic acid in climbing bean flours to a minimum level. Pretreated climbing beans (soaking in water, soaking in $2 \%$ sodium bicarbonate and steam blanching) followed by different processing were more effective in reducing phytic acid in this study than processing untreated climbing bean. Therefore, pretreatments used in this study enhance the bioavailability of minerals and improving proteins digestibility of climbing beans.

Tannins have adverse effects on biological systems because they form insoluble complexes with protein. Thus, tannins decrease protein digestibility and palatability (Hossain \& Becker, 2001). Furthermore, other adverse effects related to tannins include damage caused to the intestinal tract, toxicity of tannin absorbed from the gut and interference with the absorption of iron leads to a potential carcinogenic effect(Osagie \& Eka, 1998). Tannins content in processed climbing bean flours ranged from $0.90 \%$ to $0.04 \%$ (Table 1$)$. The raw value $(0.9 \%)$ of tannins obtained in this research was lower than $(1.7 \%)$ in raw white kidney beans and higher than $0.72 \%$ in black beans as reported by Sangronis and Machado (2007). All processing methods sig- 
Effect of processing conditions on anti-nutritional factors in climbing bean flours $\mid 39$

Table 1: Effect of pretreatments and processing conditions on anti-nutritional factors in climbing bean flours

\begin{tabular}{|c|c|c|c|c|c|}
\hline \multirow[t]{2}{*}{ Pretreatments } & \multirow[t]{2}{*}{ Processing } & \multicolumn{4}{|c|}{ Anti-nutritional factors } \\
\hline & & $\begin{array}{l}\text { Tannins } \\
(\%)\end{array}$ & $\begin{array}{l}\text { Phytates } \\
(\%)\end{array}$ & $\begin{array}{l}\text { Trypsin inhibitors } \\
\text { (TIU/g) }\end{array}$ & $\begin{array}{l}\text { Phytohemagglutinins } \\
\text { (\%) }\end{array}$ \\
\hline \multirow{4}{*}{ Untreated } & raw & $0.90^{a} \pm 0.03$ & $2.42^{a} \pm 0.00$ & $9.21^{a} \pm 0.18$ & $23.48^{a} \pm 0.06$ \\
\hline & germinated & $0.42^{c} \pm 0.01$ & $0.12^{d} \pm 0.00$ & $5.79^{c} \pm 0.02$ & $15.51^{b} \pm 0.02$ \\
\hline & roasted & $0.49^{b} \pm 0.01$ & $0.29^{c} \pm 0.01$ & $6.10^{b} \pm 0.12$ & $15.93^{b} \pm 0.04$ \\
\hline & cooked & $0.43^{c} \pm 0.10$ & $0.27^{c} \pm 0.05$ & $5.82^{c} \pm 0.07$ & $15.63^{b} \pm 0.04$ \\
\hline \multirow{4}{*}{$\begin{array}{l}\text { Steam } \\
\text { blanching } \\
\text { for } 10 \mathrm{~min}\end{array}$} & raw & $0.89^{a} \pm 0.01$ & $2.4^{a} \pm 0.01$ & $9.10^{a} \pm 0.02$ & $20.26^{a} \pm 0.10$ \\
\hline & germinated & $0.16^{d e} \pm 0.01$ & $0.04^{\bar{d}} \pm 0.04$ & $3.45^{d} \pm 0.02$ & $3.59^{d} \pm 0.02$ \\
\hline & roasted & $0.20^{d} \pm 0.60$ & $0.18^{c} \pm 0.03$ & $4.70^{c d} \pm 0.02$ & $4.80^{c d} \pm 0.01$ \\
\hline & cooked & $0.19^{d} \pm 0.03$ & $0.11^{c d} \pm 0.01$ & $3.69^{d} \pm 0.02$ & $3.63^{d} \pm 0.13$ \\
\hline \multirow{4}{*}{$\begin{array}{l}\text { Soaked in } \\
\text { water for } \\
24 \mathrm{hrs}\end{array}$} & raw & $0.73^{a} \pm 0.02$ & $1.69^{a b} \pm 0.01$ & $7.18^{a b} \pm 0.07$ & $16.03^{b} \pm 0.27$ \\
\hline & germinated & $0.04^{e} \pm 0.04$ & $0.35^{c} \pm 0.05$ & $1.60^{d d e} \pm 0.04$ & $3.16^{d} \pm 0.18$ \\
\hline & roasted & $0.44^{b} \pm 0.06$ & $0.84^{b c} \pm 0.01$ & $2.42^{d} \pm 0.03$ & $5.06^{c} \pm 0.18$ \\
\hline & cooked & $0.19^{d} \pm 0.03$ & $1.09^{b} \pm 0.06$ & $1.90^{d e} \pm 0.03$ & $3.33^{d} \pm 0.03$ \\
\hline \multirow{4}{*}{$\begin{array}{l}\text { Soaked in } \\
\mathrm{NaHCO}_{3} \\
\text { for } 24 \mathrm{hrs}\end{array}$} & raw & $0.65^{a} \pm 0.02$ & $1.42^{b} \pm 0.00$ & $6.76^{b} \pm 0.16$ & $8.27^{c} \pm 0.19$ \\
\hline & germinated & $0.04^{e} \pm 0.04$ & $0.39^{c} \pm 0.02$ & $0.80^{f} \pm 0.02$ & $2.55^{e} \pm 0.43$ \\
\hline & roasted & $0.21^{d} \pm 0.04$ & $1.30^{b} \pm 0.02$ & $1.45^{e} \pm 0.07$ & $3.15^{d} \pm 0.05$ \\
\hline & cooked & $0.11^{e} \pm 0.02$ & $1.10^{b} \pm 0.10$ & $1.22^{e} \pm 0.03$ & $2.73^{d e} \pm 0.08$ \\
\hline
\end{tabular}

Values are means $\pm \mathrm{SD}$ of 3 replications. Means within a column with the same superscript were not significantly ( $>0.05)$ different

Table 2: ANOVA summary showing significant F-ratios and p-values for anti-nutritional factors of climbing beans flours

\begin{tabular}{lllllllll}
\hline & $\begin{array}{l}\text { Tannins } \\
\text { Variations }\end{array}$ & & $\begin{array}{l}\text { Pytates } \\
(\mathbf{\%})\end{array}$ & & & \multicolumn{2}{l}{$\begin{array}{l}\text { Trypsin Inhibitors } \\
\text { (TIU/g) }\end{array}$} & $\begin{array}{l}\text { Phytohemagglutinins } \\
\text { (\%) }\end{array}$ \\
& F-ratios & p-values & F-ratios & p-values & F-ratios & p-values & F-ratios & p-values \\
\hline Pretreatments & 7.78 & 0.007 & $0.34^{*}$ & 0.778 & $2.06^{*}$ & 0.176 & 16.50 & 0.001 \\
Processing & 40.96 & 0.000 & 10.81 & 0.002 & 7.79 & 0.007 & 16.45 & 0.001 \\
Interactions & 64.94 & 0.000 & 36.88 & 0.000 & 2741.98 & 0.000 & 30526.39 & 0.000 \\
(Pretreatment $\times$ processing) & & & & & & & & \\
\hline
\end{tabular}

*Not significant at $\mathrm{p}>0.05$

nificantly decreased tannins content in climbing bean flours. These results were in agreement with those of Rehman and Shah (2004) who found that tannins content of black red kidney beans was significantly decreased after soaking followed by different processing methods. The loss of tannins during soaking and cooking was probably due to the leaching of the tannins in soaking and cooking medium. Soaking and cooking, and discarding the soaking and cooking water did not eliminate all the tannins in climbing bean flours. Therefore, soaking and cooking could be recommended in the preparation of climbing beans because the antioxidant activity attributed to this compound is preserved. The highest loss $(0.16 \%$ to $0.04 \%)$ of tannins was found in pretreated climbing beans followed by germination. This could be explained by the activation of hydrolysable enzymes polyphenolases involved in breakdown of other various compound in grains that causes the loss of tannins during germination (Reddy, Pierson, Sathe, \& Salunkhe, 1984). Therefore, the results revealed that germination is a good way to reduce tannins in climbing bean flours at safe level for consumers. 
Trypsin inhibitors are anti-nutritional factors that inhibit the action of trypsin and pepsin in the gut and subsequently prevent absorption of protein (Tanwilson et al., 1987). Trypsin inhibitors found in climbing beans in this study varied from $9.21 \mathrm{TUI} / \mathrm{g}$ to $0.80 \mathrm{TUI} / \mathrm{g}$ (Table 1 ). The pretreatments alone did not significantly $(\mathrm{p}>0.05)$ affect trypsin inhibitors in climbing bean flours but pretreatments followed by different processing conditions significantly $(\mathrm{p}<0.05)$ decreased it. The highest reduction was observed in pretreatment followed by germination (Table 1). This was probably due to utilization of trypsin inhibitor in early stage of germination as reported by Burbano, Muzquiz, Ayet, Cuadrado, and Pedrosa (1999) and Sangronis and Machado (2007). According to Sangronis and Machado (2007), germination is a catabolic process which causes the degradation of substances present in cotyledon to be used in developing and growing of embryo. It was also reported that during germination enzymes are immobilized like protease to degrade proteins including proteases inhibitors (Siddhuraju, Becker, \& Makkar, 2000). Therefore, germinated climbing bean flours can be used as functional food due to its low protein inhibitor content and improved protein digestibility. According to Pugalenthi, Vadivel, and Siddhuraju (2005), the presence of trypsin inhibitor in diets leads to the formation of irreversible trypsin enzyme-trypsin inhibitor complexes, causing decreases in trypsin in the intestine and subsequently in digestibility of dietary proteins that leads to reduce animal growth. This situation causes pancreatic hyperplasia to the animal resulting from an increase of secretary activity of pancreases as reported by Liener (1994). In this study, pretreated climbing beans by soaking in sodium bicarbonate, soaking in water followed by processing such as germination, cooking and roasting, reduced trypsin inhibitors to acceptable level. This decrease was attributed to soaking climbing beans in medium containing sodium bicarbonate salts. The salt increases the porosity of seed coat and help the leaching of trypsin inhibitors into the soaking medium (Salve \& Mehrajfatema, 2011).

However, the moderate reduction of trypsin inhibitors was noted in blanched climbing beans followed by processing. The contents of trypsin inhibitors in roasted beans were the highest. This could be attributed to the presence of non-protein compounds resulting from browning reactions which could increase the residue of trypsin inhibitors after thermal processing (Sangronis \& Machado, 2007).

Phytohemagglutinins or lectins are type of protein that can bind to cell membranes. According to Palul (2014), lectins can bind to intestinal epithelial cells, where they may impair nutrient absorption and cause damage that may allow infiltration of bacterial cells into the blood stream. However, Jones and Boulter (1983) reported that the body uses lectins to achieve many basic functions such as cell to cell adherence, inflammatory modulation and programmed cell death. The phytohemagglutinins content of climbing bean flours varied from $23.48 \%$ to $2.55 \%$ (Table 1 ). The observed level of $23.48 \%$ in raw climbing beans flours was lower than $33.18 \%$ reported by Olanipekun, Omenna, Olapade, Suleiman, and Omodara (2015) in kidney beans. According to Hamid and Masood (2009), the value (23.48\%) obtained in raw climbing was not within a safe value which is less than $20 \%$. Therefore, climbing beans must be pretreated and processed before consumption to prevent adverse effect. The germination showed high reduction of phytohemagglutinins of climbing bean flours compared to other processing conditions (Table 1). This was attributed to hydrolysis of storage protein into amine acid reserved for growing seedling as reported by Akande and Fabiyi (2010). Therefore, as lectins are proteins in nature, during germination of climbing beans, they are also hydrolyzed which causes their reduction.

Pretreatments and processing conditions significantly decreased tannins content in climbing bean flours (Table 2). In this study, the results showed that pretreatments did not significantly $(\mathrm{p}>0.05)$ affect phytate content in climbing bean flours but processing conditions significantly $(\mathrm{p}<0.05)$ decreased it as shown in Table 2. The pretreatments alone did not significantly $(\mathrm{p}>0.05)$ affect trypsin inhibitors in climbing bean flours but pretreatments followed by different processing conditions significantly $(\mathrm{p}<0.05)$ decreased trypsin inhibitors in climbing beans flours (Table 2). Pretreatments and processing conditions significantly $(\mathrm{p}<0.05)$ de- 
Effect of processing conditions on anti-nutritional factors in climbing bean flours $\mid 41$

creased phytohemagglutinins in climbing beans but the highest significant decrease was observed in pretreatment followed by different processing methods (Table 1).

\section{Conclusions}

This study found that phytic acid reduced from $2.42 \%$ to $0.04 \%$. The highest content of phytic acid in untreated climbing beans and the lowest content was found in steamed climbing bean followed by germination. Tannins content ranged from $0.90 \%$ to $0.04 \%$. The highest and lowest contents of tannins were in untreated climbing beans and in soaked climbing beans in water for 24 hours followed by germination respectively. Trypsin inhibitors were reduced from $9.21 \mathrm{TUI} / \mathrm{g}$ to $0.80 \mathrm{TUI} / \mathrm{g}$. The raw climbing bean had the highest content of trypsin inhibitors while the lowest was found in climbing beans soaked in $2 \%$ sodium bicarbonate followed by germination. The highest level of phytohemagglutinins was $23.48 \%$ in untreated climbing bean; the lowest level was $2.55 \%$ in climbing beans soaked in $2 \%$ sodium bicarbonate followed by germination. Pretreatments (soaking in water, soaking in $2 \%$ sodium bicarbonate and steam blanching for $10 \mathrm{~min}$ ) followed by different processing reduced anti-nutritional factors at respective acceptable levels. Pretreatments followed by germination had the lowest contents of anti-nutritional factors. The utilization of flour from germinated climbing bean seeds in Rwandan households, restaurants and industries is a good option to reduce the anti-nutritional factors as germination is an inexpensive method in terms of time, energy and fuel.

\section{References}

Akande, K. E. \& Fabiyi, E. F. (2010). Effect of processing methods on some antinutritional factors in legume seeds for poultry feeding. International Journal of Poultry Science, 9(10), 996-1001. doi:10.3923/ijps. 2010.996.1001
Asare-Marfo, D., Birol, E., Katsvairo, L., Manirere, J. d., Maniriho, F., \& Roy, D. (2011). Farmer choice of bean varieties in rwanda: lessons learnt for harvestplus delivery and marketing strategies. Unpublished project report. Washington, DC: International Food Policy Research Institute, HarvestPlus.

Broughton, W. J., Hernandez, G., Blair, M., Beebe, S., Gepts, P., \& Vanderleyden, J. (2003). Beans (phaseolus spp.) - model food legumes. Plant and Soil, 252(1), 55128. doi:10.1023/A:1024146710611

Burbano, C., Muzquiz, M., Ayet, G., Cuadrado, C., \& Pedrosa, M. M. (1999). Evaluation of antinutritional factors of selected varieties of phaseolus vulgaris. Journal of the Science of Food and Agriculture, 79(11), 1468-1472. doi:10 . 1002 / (SICI ) 1097 0010(199908) 79:11〈1468::AID - JSFA387〉 3.0.CO;2-G

Durward, S. S., Jerry, N., Wai-kit, C., \& Nip, Y. (1997). Processing vegetable (science and technology). Lancaster: Taylor \& Francis group.

Egli, I., Davidsson, L., Juillerat, M. A., Barclay, D., \& Hurrell, R. F. (2002). The influence of soaking and germination on the phytase activity and phytic acid content of grains and seeds potentially useful for complementary feeding. Journal of Food Science, 67(9), 3484-3488. doi:10.1111/j.1365-2621. 2002.tb09609.x

Hamid, R., Masood, A. et al. (2009). Dietary lectins as disease causing toxicants. Pakistan Journal of Nutrition, 8(3), 293-303. doi:10.3923/pjn.2009.293.303

Hossain, M. A. \& Becker, K. (2001). Nutritive value and antinutritional factors in different varieties of sesbania seeds and their morphological fractions. Food Chemistry, 73(4), 421-431. doi:10.1016/S03088146(00)00317-4

Jones, P. M. B. \& Boulter, D. (1983). The cause of reduced cooking rate in phaseolus-vulgaris following adverse storage-conditions. Journal of Food Science, 48(2), 623-649. doi:10.1111/j.13652621.1983.tb10804.x 
Kar, A., Choudhary, B. K., \& Bandyopadhyay, N. G. (1999). Preliminary studies on the inorganic constituents of some indigenous hypoglycaemic herbs on oral glucose tolerance test. Journal of Ethnopharmacology, 64(2), 179-184. doi:10.1016 / S03788741(98)00118-4

Kumar, V., Sinha, A. K., Makkar, H. P. S., \& Becker, K. (2010). Dietary roles of phytate and phytase in human nutrition: a review. Food Chemistry, 120(4), 945-959. doi:10. 1016/j.foodchem.2009.11.052

Larochelle, C. \& Alwang, J. (2014). Impacts of improved bean varieties on food security in rwanda. In Aaea annual meeting.

Liener, I. (1994). Foodborne disease handbook. In Hui (Ed.), (Chap. Anti-nutritional factors related to protein and amino acids, pp. 261-309). New York: Mercer Dekker.

Minihane, A. M. \& Rimbach, G. (2002). Iron absorption and the iron binding and antioxidant properties of phytic acid. International Journal of Food Science and Technology, 37(7), 741-748.

Nwosu, J. N. (2011). The effects of processing on the anti-nutritional properties of oze bosqueia angolensis seed. Journal of American Science, 7(1), 1-6.

Oatway, L., Vasanthan, T., \& Helm, J. H. (2001). Phytic acid. Food Reviews International, 17(4), 419-431. doi:10.1081/FRI100108531. eprint: http://dx.doi.org/10. 1081/FRI-100108531

Olanipekun, O. T., Omenna, E. C., Olapade, O. A., Suleiman, P., \& Omodara, O. G. (2015). Effect of boiling and roasting on the nutrient composition of kidney beans seed flour. Journal of Food Science, 4 (2), 24-29.

Osagie, A. \& Eka, F. (1998). Some antinutritional constituents in some food items grown in nigeria. Tropical Science, 36, 109115.

Oshodi, A. A. \& Aletor, V. A. (1993). Functional properties of haemagglutinins (lectins) extracted from some edible varieties of lima beans (phaseolus lunatus linn). International Journal of Food Sciences and $\mathrm{Nu}$ trition, 44(2), 133-136. doi:10 . 3109/ 09637489309017431. eprint: http://dx.doi. org/10.3109/09637489309017431
Palul, B. (2014). Anti-nutritional factor in food and their effects. Journal of Academic Industrial Research, 3(6), 227-5213.

Pearson, S. D. (1976). The chemical analysis of food 7th edition. Churchill Livingstons.

Pugalenthi, M., Vadivel, V., \& Siddhuraju, P. (2005). Alternative food/feed perspectives of an underutilized legume mucuna pruriens var. utilis - a review. Plant Foods for Human Nutrition, 60(4), 201. doi:10. 1007/s11130-005-8620-4

Reddy, N. R., Pierson, M. D., Sathe, S. K., \& Salunkhe, D. K. (1984). Chemical, nutritional and physiological-aspects of dry bean carbohydrates - a review. Food Chemistry, 13(1), 25-68. doi:10 . 1016 / 0308 8146(84)90026-8

Rehman, Z. \& Shah, W. H. (2004). Quality improvement of legumes through the application of various physic-chemical treatments. Pakistan Journal of Food Sciences, 6, 6365.

Salve, R. \& Mehrajfatema, Z. (2011). Effect of different pre-treatment on trypsin inhibitor activity and nutritional composition of moth bean and its utilisation in fortified cake. World Journal of Dairy and Food Science, 6(2), 212-218.

Sangronis, E. \& Machado, C. J. (2007). Influence of germination on the nutritional quality of phaseolus vulgaris and cajanus cajan. $L W T$ - Food Science and Technology, 40(1), 116120. doi:10.1016/j.lwt.2005.08.003

Shamsuddin, A. M. (2002). Anti-cancer function of phytic acid. International Journal of Food Science and Technology, 37(7), 769782. doi:10.1046/j.1365-2621.2002.00620.x

Siddhuraju, P., Becker, K., \& Makkar, H. P. S. (2000). Studies on the nutritional composition and antinutritional factors of three different germplasm seed materials of an under-utilized tropical legume, mucuna pruriens var. utilis. Journal of Agricultural and Food Chemistry, 48(12), 6048-6060. doi:10.1021/jf0006630

Tanwilson, A. L., Chen, J. C., Duggan, M. C., Chapman, C., Obach, R. S., \& Wilson, K. A. (1987). Soybean bowman-birk trypsin isoinhibitors - classification and report of a glycine-rich trypsin-inhibitor 
Effect of processing conditions on anti-nutritional factors in climbing bean flours $\mid 43$

class. Journal of Agricultural and Food Chemistry, 35(6), 974-981. doi:10.1021/ jf00078a028

Yoon, J. H., Thompson, L. U., \& Jenkins, D. J. (1983). The effect of phytic acid on in vitro rate of starch digestibility and blood glucose response. The American Journal of Clinical Nutrition, 38(6), 835-842. 